\title{
FEATURES OF THE PETROCHEMICAL INDUSTRY OF THE REPUBLIC OF KAZAKHSTAN AND ASSESSMENT OF ITS COMPETITIVENESS
}

A. Kadyrbergenova*, N. Ismagulova, R. Bagitova, M. Azhmagambetova Atyrau University of oil and gas named after S. Utebayev, Atyrau, Kazakhstan e-mail: asel-k-80@mail.ru

Summary: The petrochemical market is a necessary element of resource supply for all sectors of the economy. In its development, petrochemicals are ahead of related industries, such as oil production and refining. Even today, the volume of sales in monetary terms significantly exceeds the volume of sales of oil or petroleum products. In the future, the global petrochemical market will continue to grow faster than the oil and petroleum products market. The annual growth of the production rate of multi-tonnage plastics is expected to reach 5\% by 2023, and the production of polyester fibers- $6 \%$. At the same time, the growth rate of oil demand, according to the Energy Information Agency (USA), will be $1.7 \%$ per year, including in developed countries about $1 \%$ per year. The petrochemical industry is characterized by rapid development of scientific and technological progress, increasing the efficiency of public production.

Key words: petrochemical industry, products, competitiveness, competitiveness assessment

МРНТИ06.52

ӘӨЖ 330.34 https://doi.org/10.51579/1563-2415.2021-2.14

\section{ҚАЗАҚСТАН РЕСПУБЛИКАСЫНЫН ЖАЛПЫ ІШКІ ӨНІМІНЕ ҚОСАТЫН ШАҒЫН ЖӘНЕ ОРТА КӘСІПКЕРЛІКТІН ҚАРЖЫЛАЙ УЛЕСІН ТАЛДАУ А.Д. Тлеубекова *, А.Б. Кутпанова, Г. К. Баймуратова, А. И. Ондасынова Алматы Экономика және статистика академиясы, Алматы, Қазакстан e-mail: atleubekova@mail.ru}

Түйін. Oсы зерттеудің ерекше қызылушыылывы мен өзектілігі шавын және орта кәсіпкерліктің нарықтың қалыптасуы мен дамуының қозваушы күші ретіндегі маңыздыльвына байланыстыл. Шавын және орта кәсіпорындар тұтынушылық тауарлар мен қызметтерді өндіруді едауір және айтарлықтай күрделі салымдарсыз кеңейтеді, халықтың өмір сүру жавдайларын теңестіруге көмектеседі, өндіріске еңбек, материалдық және қаржылық ресурстарды тартады, өндірісті монополиясыздандыруды жеделдетеді, бәсекелестіктің дамуына ықппал етеді, қовамның орта таптарының негізі ретінде меншік иелерінің жаппай қабатын қалыптастыруга негіз болады, оның тұрақтылыьыыныңц кепілі, материалдық бюджет түсімдері мен тұрақты экономикальқ өсудің көзі ретінде қыззмет етеді.

Шазын және орта бизнесті дамыту бәсекеге қабілетті нарықтық тетіктің күрделі синтезі мен ірі, орта және шавын өндірісті мемлекеттік реттеуді жүзеге асыратын икемді аралас экономиканы қалыптастыруга, меншіктің әртүрлі нысандарын және экономиканың оларва барабар моделін біріктіруге жаһандық тенденцияларва жауап бередi.

Түйін сөздер. Шазын және орта кәсіпкерлік, жалпь ішкі өнім, жаңуашылдық пен инновачиялық қызмет, қаржыльық жавдай, өсу қарқыныны, экономикалық өсу, тұтынушиылық сұранысс

Негізгі ережелер. Мақаланы жазу барысында келесі негізгі нәтижелерге қол жеткізілді: Қазақстан Республикасының жалпы ішкі өніміне қосатын шағын және орта 
кәсіпкерліктің қаржылай үлесіне талдау, жалпы ішкі өніміне қосқан шағын және орта бизнестің үлесіне арналған 2021, 2022 жылдарға болжам жасалды.

Кіріспе. Шағын және орта кәсіпкерліктің жалпы мақсаты - өндіріс негізінде пайда табу. Қалған мақсаттар - сатуды ұлғайту және ассортиментті кеңейту - келесі көрсеткіштер бойынша бағалануы мүмкін: қарастырылып отырған кезеңдегі сатылымның алдыңғы деңгеймен салыстырғанда өсуі; интенсивті факторларды қолдану есебінен өндіріс көлемінің артуы; өндіріс ырғағы; кәсіпорын ассортиментіндегі өнім атауларының саны; өнімнің жекелеген түрлерінің олардың жалпы өндірісі мен сатылуындағы үлесі. Өнімнің сапасын жақсарту және бәсекеге қабілеттілігін қамтамасыз етуді мынадай көрсеткіштер бойынша бағалауға болады: кәсіпорынның жалпы өнім көлеміндегі жаңа прогрессивті өнімдердің үлесі; жақсырақ және бәсекеге қабілетті өнімді сатудан түскен пайда және т.б [1].

Әдістері. Қазіргі экономикалық жағдайда кәсіпкерліктің экономикалық дамудағы рөлі белсенді түрде талқылануда, ал кәсіпкерлікті өлшеу және зерттеу үшін статистика әдіснамасын әзірлеу көптеген статистикалық басқармалар мен халықаралық ұйымдар үшін қызметтің басым бағытына айналуда.

Нәтижелер мен талқылау. Бүгінде шағын және орта кәсіпкерліктің Қазақстанның экономикалық және әлеуметтік проблемаларын шешуде зор әлеуеті бар екеніне ешкімнің де күмәні жоқ. Қазақстандық шағын кәсіпорындар қазірдің өзінде жаңа жұмыс орындарын құруға, бюджеттің кіріс бөлігіне, жаңашылдық пен инновациялық қызметті ынталандыруға, сондай-ақ Қазақстан Республикасындағы әлеуметтік тұрақтылықты нығайтудың аса маңызды шарты болып табылатын меншік иелерінің орта тобын қалыптастыруға өз үлестерін қосуда [2]

Шағын кәсіпкерлік нарық конъюнктурасының өзгеруіне жедел ден қоя отырып, экономикаға қажетті икемділік береді. Шағын компаниялар тұтынушылық сұраныстың өзгеруіне тез жауап бере алады және осыған байланысты тұтынушылық нарықта қажетті тепе-теңдікті қамтамасыз етеді. Шағын бизнес бәсекелестік ортаны қалыптастыруға айтарлықтай үлес қосады, бұл біздің экономикамыз үшін өте маңызды.

Кестеде мәліметтері бойынша Қазақстан Республикасының жалпы ішкі өніміне қосқан шағын және орта кәсіпкерліктің үлесінің өсімшесі, өсу қарқыны, өсімше қарқыны зерттеу жүргізілді. 2007 жылы 2005 жылға қарағанда 981381 млн теңге өсімше көрсетсе, 2006 жылмен салыстырғанда 595872 млн теңге өсімшені көрсеткен. Өсу қарқынына тоқталатын болсақ 2005 жылға қарағанда 163,5\% өсу қарқынын көрсетті, 2006 жылмен салыстырғанда 130,8\% өсу қарқынын көрсетіп отыр. Өсімше қарқынында қарайтын болсақ 2005 жылмен салыстырып көргенімізде 63,5\% болса, 2006 жылмен салыстырғанда 30,8\% өсу қарқынын көрсетті.

2010 жылға қарайтын болсақ 2005 жылмен салыстырып көргенде 5731723 млн теңге өсімшені көрсетті, 2009 жылмен салыстырғанда 1908842 млн теңге өсімшені құрады. Өсу қарқынына қарайтын болсақ 2005 жылмен салыстырғанда 471,2\% көрсетті, ал 2009 жылмен салыстырып қарасақ өсу қарқыны 135,5\% көрсетті. Өсімше қарқыны 2005 жылға қарағанда 371,2\% артық болды, 2009 жылға қарағанда 35,5\% артық болғанын байқауға болады.

2015 жылғада талдау жасасақ 2005 жылға қарағанда 14155349 млн теңге өсімшені құрады, 2014 жылмен салыстырғанда аса қатты өзгеріс сезілмей 131324 млн теңгені көрсетті. 2005 жылмен салыстырғанда өсу қарқыны 1016,7\% көрсетті, 2014 жылға қарағанда 100,8\% өсу қарқынын көрсетті. Өсімше қарқынына қарайтын болсақ 2015 жылы 2005 жылмен салыстыра қарағанда 916,7\% құрады, 2014 жылмен салыстырғанда 0,8\% өсімше қарқынын көрсетті. 
Kecme 1

Қазақстан Республикасының жалпы ішкі өніміне қосатын шазын және орта кәсіпкерліктің қ̧аржылай үлесін талдау

\begin{tabular}{|c|c|c|c|c|c|c|c|}
\hline \multirow{2}{*}{$\begin{array}{c}\text { Жыл- } \\
\text { дар }\end{array}$} & \multirow{2}{*}{$\begin{array}{c}\text { ҚР ЖІӨ-ге } \\
\text { қосылатын } \\
\text { қаржы, } \\
\text { млн тг } \\
\text { у }\end{array}$} & \multicolumn{2}{|c|}{ Өсімше } & \multicolumn{2}{|c|}{$\begin{array}{c}\text { Өсу } \\
\text { қарқыны }\end{array}$} & \multicolumn{2}{|c|}{$\begin{array}{c}\text { Өсімше } \\
\text { қарқыны }\end{array}$} \\
\hline & & базистік & тізбек & базистік & тізбек & базистік & тізбек \\
\hline 2005 & 1544056 & & & & & & \\
\hline 2006 & 1929565 & 385509 & 385509 & 124,96729 & 124,967294 & 24,9672939 & 24,9672939 \\
\hline 2007 & 2525437 & 981381 & 595872 & 163,5586 & 130,8812 & 63,55864 & 30,88116 \\
\hline 2008 & 4872965 & 3328909 & 2347528 & 315,59509 & 192,955318 & 215,595095 & 92,9553182 \\
\hline 2009 & 5366937 & 3822881 & 493972 & 347,58694 & 110,136991 & 247,58694 & 10,1369905 \\
\hline 2010 & 7275779 & 5731723 & 1908842 & 471,2121 & 135,5667 & 371,21212 & 35,56669 \\
\hline 2011 & 7603805 & 6059749 & 328026 & 492,45656 & 104,508466 & 392,456556 & 4,50846569 \\
\hline 2012 & 8255123 & 6711067 & 651318 & 534,63883 & 108,565685 & 434,638834 & 8,56568521 \\
\hline 2013 & 9165412 & 7621356 & 910289 & 593,59324 & 111,026959 & 493,593238 & 11,0269587 \\
\hline 2014 & 15568081 & 14024025 & 6402669 & 1008,2588 & 169,85686 & 908,258833 & 69,8568597 \\
\hline 2015 & 15699405 & 14155349 & 131324 & 1016,764 & 100,8435 & 916,76396 & 0,843546 \\
\hline 2016 & 19609010 & 18064954 & 3909605 & 1269,9675 & 124,902886 & 1169,96754 & 24,9028864 \\
\hline 2017 & 23241125 & 21697069 & 3632115 & 1505,1996 & 118,522684 & 1405,19962 & 18,5226842 \\
\hline 2018 & 26473049 & 24928993 & 3231924 & 1714,5135 & 113,906057 & 1614,51353 & 13,9060566 \\
\hline 2019 & 32386960 & 30842904 & 5913911 & 2097,525 & 122,3394 & 1997,525 & 22,33936 \\
\hline
\end{tabular}

Кестеде көріп тұрғандай 2019 жылға қарасақ 2005 жылмен салыстырғанда өсімше жоғарғы деңгейде болып 30842904 млн теңгені көрсетті, ал 2018 жылмен салыстыра қарасақ өсімше 5913911 млн теңгені көрсетті. Өсу қарқынына тоқталсақ, 2005 жылмен салыстыра алғанда 2097,5\% көрсетсе, 2018 жылмен салыстыра алғанда 122,3\% көрсетті. Өсімше қарқыны 2005 жылмен салыстырып көрсек 1997,5\% болды, ал 2018 жылмен салыстырып көрсек 22,3\% болды. Осы кесте мәліметтерін негізге ала отырып өсу динамикасын жасай аламыз.

\section{Қазақстан Республикасындағы ЖІӨ-ге} қосылған қаржы, млн тг

\section{0}

30000000

20000000

10000000

Сурет 1. Қазақстан Республикасындағы ЖІӨ-ге косылған қаржы, млн. тг 
Диаграмма мәліметтері бойынша жалпы Қазақстан Республикасы бойынша шағын және орта кәсіпкерліктің жалпы ішкі өнімге қосқан қаржылай үлесі көрсетілген. Елімізде шағын және орта бизнестің жалпы ішкі өнімге қосатын үлесі жыл сайын артып отырған. Бірақ 2014 жылдан бастап өте қарқынды түрде дамып отырған. Оны кестеден толық аңғаруға болады. 2005 жылға тоқталатын болсақ, ол кездегі көрсеткін небәрі 1544056 млн теңгені құраған болатын. Ал 2007 жылы 2005 жылмен салыстырғанда 981381 млн теңгеге өсіп, 2525437 млн теңгені құрады. 2010 жылға зер салсақ бірден 4750342 млн теңгеге өсіп, 7275779 млн теңгені құрады. 2015 жылы 2010 жылмен салыстырғанда екі есеге өсіп, яғни 8423626 млн теңгеге өсіп, 15699405 млн теңгені көрсетті. Осы көрсеткішті жоғарғы деңгей деп санап отырғанда 2019 жылы 32386960 млн теңге болып, 16687555 млн теңге өсім көрсетті. Бұл көрсеткіштермен ғана шектеліп қалмай шағын және орта бизнес қарқынды түрде дамып келе жатыр.

Kecme 2

Қазақсстан Республикасының жалпы ішкі өніміне құосқан шадын және орта бизнестің үлесіне арналван 2021, 2022 жылдарва болжам

\begin{tabular}{|l|l|l|l|}
\hline \multicolumn{1}{|c|}{ Жылдар } & \multicolumn{1}{|c|}{$\begin{array}{c}\text { ҚР ЖІӨ-ге қосылған } \\
\text { қаржы, млн тг }\end{array}$} & \multicolumn{1}{|c|}{ Жылдар } & $\begin{array}{c}\text { ҚР ЖІӨ-ге } \\
\text { қосылған қаржы, } \\
\text { млн тг }\end{array}$ \\
\hline 2005 & 1544056 & 2014 & 15568081 \\
\hline 2006 & 1929565 & 2015 & 15699405 \\
\hline 2007 & 2525437 & 2016 & 19609010 \\
\hline 2008 & 4872965 & 2017 & 23241125 \\
\hline 2009 & 5366937 & 2018 & 26473049 \\
\hline 2010 & 7275779 & 2019 & 32386960 \\
\hline 2011 & 7603805 & 2020 & 35847392 \\
\hline 2012 & 8255123 & 2021 & 37498243 \\
\hline 2013 & 9165412 & 2022 & 42454728 \\
\hline Eскертпе: ҚР статистика агенттігінің мәліметі бойьншиа [3] & \\
\hline
\end{tabular}

Жалпы экономика үшін шағын және орта бизнестің қызметі оның икемділігін арттырудың маңызды факторы болып табылады.

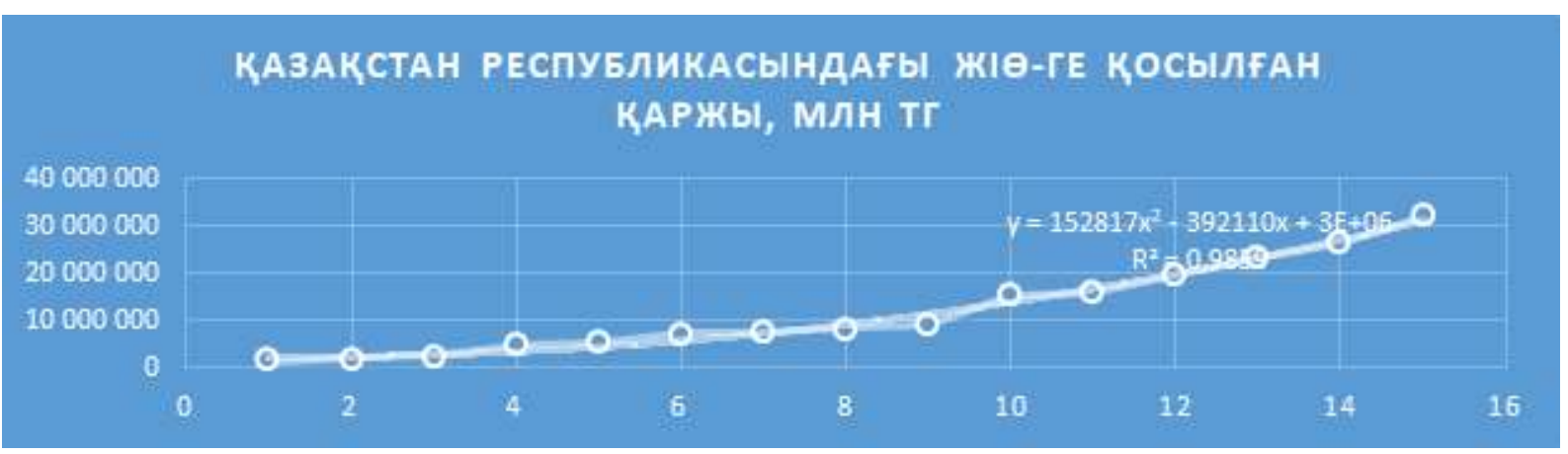

Сурет 2. Қазақстан Республикасының жалпы ішкі өніміне қосқан шағын және орта бизнестің үлесіне арналған 2021, 2022 жылдарға болжам 
Кесте мәліметтері бойынша Қазақстан Республикасының жалпы ішкі өніміне қосатын шағын және орта кәсіпкерліктің қаржылай үлесіне алдағы 2021, 2022 жылдарға болжам жасалды. Болжам бойынша 2021 жылы қосатын үлесі 37498243 млн теңге, 2022 жылы 42454728 млн теңге болады деп күтілуде. Егерде осы болжам бойынша шағын және орта кәсіпкерлік қарқынды түрде дамыса еліміздің экономикалық қозғаушы күшіне айналып дамыған он елдің қатарына кіруімізге себепші болады.

Қорытынды. Шағын және орта бизнес еліміздің қозғаушы күшіне айналу керек дегенге толығырақ назар аударып, өзектілігін анықтадық. Шағын және орта бизнестің өзі жұмыссыздық деңгейін төмендетіп, қалыпты ұстап тұруға себепші болатын негізгі фактор. Шағын және орта бизнес аясында жұмыс істейтін азаматтар жыл санап артып келе жатқанын байқауға болады. Бұл қоғамның өзі жекешелендіруге, бәсекеге қабілетті болуға барынша бет бұрып жатқанын аңғартады. Зерттеу негізінде жалпы ішкі өнімге қосқан шағын және орта кәсіпкерліктің үлесіне тереңірек үңілген болатынбыз. 2005 жылдары жалпы ішкі өнімге мардымсыз ғана қаражат түсірген болса, 2019 жылы 32386960 млн теңге қаражат түсірген. Ал қазіргі таңда шағын және орта бизнесті қолдайтын түрлі бағдарламалар жүзеге асырылуда. Мысалға «Бизнестің жол картасы-2020», «Astana ZhasStarT» бағдарламарын алуға болады. Сонымен қатар елімізде шағын және орта кәсіпкерлікке толық қолдау білдіретін «Даму» кәсіпкерлікті дамыту қоры» акционерлік қоғамы өз жұмысын белсене атқаруда [4]. Қорытындылай келгенде елімізде шағын және орта кәсіпкерліктің қарқынды дамып жатқаны, еліміздің болашағының берік болатынын білдіреді. Бірақ әліде мемлекет тарапынан қолдаулар керек. Субсидиялар мен жеңілдіктер көбірек бөлінсе, шағын және орта бизнес тоқтаусыз дамитыны көрсетеді. Мемлекеттің экономикалық қозғаушы күшіне шағын және орта кәсіпкерлік айналуы керек. Талдаулар жасағаннан, болжамдар жасағаннан осындай ой түюге болады. Егерде шағын және орта кәсіпкерлік еліміздің экономикалық қозғаушы күшіне айналған жағдайда кез келген дағдарысты еңсеріп, дамыған елдер қатарынан көрінуге болады. Еліміздің ішкі тұтынушы нарығын толығымен қамтамасыз етіп, экспорт деңгейін көтеруге толық жол ашады.

\section{Пайдаланылған әдебиеттер тізімі:}

1.Балдина, Ю.А. Роль и место субъектов малого и среднего предпринимательства в современных экономических условиях / Вестник Удмуртского университета. Серия Экономика и право. 2018. Т. 26. № 4. [Электронный источник]

2.Горфинкель, В.Я. Малое предпринимательство: организация, управление, экономика: учебное пособие/В.Я. Горфинкель, С.В. Земляк, О.М. Маркова и др. М.: Вузовский учебник: ИНФРА-М, 2019 - 89с.

3. https://stat.gov.kz/

4.http://astana.gov.kz/kz/news/news/16760Шағын және орта бизнеске көмек беретін мемлекеттік бағдарламалар

Spisok literatury:

1. Baldina, Iu. A. Rol i mesto subieektov malogo i srednego predprinimatelstva $\mathrm{v}$ sovremennykh ekonomicheskikh usloviiakh / Vestnik Udmurtskogo universiteta. Seriia Ekonomika i pravo. 2018. T. 26. № 4. [Elektronnyi istochnik]

2. Gorfinkel, V. Ia. Maloe predpriiatie: organizatsiia, upravlenie, ekonomika: uchebnoe posobie/V. Ia. Gorfinkel, S. V. Zemliak, O. M. Markova i dr. M.: Vuzovskii uchebnik: INFRAM, 2019-89s.

\section{3. https://stat.gov.kz/}

4.http://astana.gov. kz/KZ/news/news/16760 gosudarstvennye programmy pomoshchi naseleniiu i srednemu biznesu 


\section{АНАЛИЗ ФИНАНСОВОГО ВКЛАДА МАЛОГО И СРЕДНЕГО ПРЕДПРИНИМАТЕЛЬСТВА В ВАЛОВОЙ ВНУТРЕННИЙ ПРОДУКТ РЕСПУБЛИКИ КАЗАХСТАН}

\section{А.Д. Тлеубекова*, А.Б. Кутпанова , Г. К. Баймуратова, А. И. Ондасынова}

Алматинская академия экономики и статистики, г. Алматы, Казахстан e-mail: atleubekova@mail.ru

Резюме. Особый интерес и актуальность данного исследования обусловлена значимостью малого и среднего предпринимательства как движущей силы становления $и$ развития рынка. Малье и средние предприятия расширяют производство потребительских товаров и услуг значительно и без существенных капитальных вложений, способствуют выравниванию условий жизни населения, вовлекают в производство трудовые, материальные и финансовые ресурсы, ускоряют демонополизачию производства, способствуют развитию конкуренции, служат основой для формирования массового слоя собственников как основы среднего класса общества., служит гарантом его стабильности, источником поступления материальных средств бюджета и устойчивого экономического роста.

Ключевые слова. Малое и среднее предпринимательство, валовой внутренний продукт, инновачии и инновачионная деятельность, финансовое состояние, темпь роста, экономический рост, потребительский спрос

\section{ANALYSIS OF THE FINANCIAL CONTRIBUTION OF SMALL AND MEDIUM-SIZED BUSINESSES TO THE GROSS DOMESTIC PRODUCT OF THE REPUBLIC OF KAZAKHSTAN}

\section{A. D. Tleubekova*, A. B. Kutpanova, G. K. Baymuratova, A. I. Ondasynova}

Almaty Academy of Economics and Statistics, Almaty, Kazakhstan

e-mail: atleubekova@mail.ru

Summary. The special interest and relevance of this study is due to the importance of small and medium-sized businesses as a driving force for the formation and development of the market. Small and medium-sized enterprises expand the production of consumer goods and services significantly and without significant capital investments, contribute to the equalization of the living conditions of the population, involve labor, material and financial resources in production, accelerate the demonopolization of production, promote competition, and serve as the basis for the formation of a mass layer of owners as the basis of the middle class of society., serves as a guarantor of its stability, a source of income from the budget's material resources and sustainable economic growth.

Key words. Small and medium-sized enterprises, gross domestic product, innovation and innovation activity, financial condition, growth rate, economic growth, consumer demand. 